\title{
The Implementation of Good Corporate Governance (GCG), Corporate Social Responsibility (CSR) Toward Stock Return and Ethics as Moderating Variables
}

\author{
Verliani Dasmaran ${ }^{1} \quad$ Yvonne Augustine Sudibyo $^{2}$ \\ 1.Accounting Doctoral Student, Trisakti University Indonesia \\ 2.Lecturer, Trisakti University Indonesia
}

\begin{abstract}
The study have aim to test how to implemented of Good Governance of corporate (GCG), Social Responsibility of corporate (CSR), toward Stock Return and Ethics as a moderating variable. This study uses financial performance, namely ROE and Size as a control variable. The research method uses secondary data multiple regression testing with an analysis unit of 57 annual reports of manufacturing companies registered at idx.co.id processing data using SPSS 20. Output this study to prove that Good Governance of corporate (GCG) have a positive impact toward stock return or advantage of stock. Social Responsibility of corporate (CSR) have the effect positive toward return Stock. And Ethics cannot strengthen the influence to Good Governance of Corporate toward Stock Returns; Ethics can strengthen the leverage Social Responsibility of Corporate to Stock return. The limitation in this study is focus on manufacturing companies not all sectors. The implication of the research is on the theory and policy of the company in implementation of ethics in the implementation of GCG and CSR
\end{abstract}

Keywords: Good Corporate Governance, Corporate Social Responsibility, Stock Return, Ethics

DOI: $10.7176 /$ RJFA/10-12-15

Publication date:June $30^{\text {th }} 2019$

DOI :10.7176/RJFA

Publication Date :

1. Introduction

Enrone case in (2001) proved the giant company could be destroyed not only because of the decline in market share or the abandonment of customers but the impact of the company's lack of good governance and even worse there were violations of business ethics carried out by Enron so that the impact so large on stock prices that it continued to decline until it could not be saved and became a case that greatly hit the economy of the USA, and became the spotlight of the world with many violations of professional ethics committed by the parties involved in the destruction of Enron.

Governance is very important in business strategy because governance is a system operated by humans to run an entity how much governance is successfully implemented depends on integrity and commitment from the internal (Board) as significant executor in the application of Good Corporate Governance. In accordance with agency theory, good governance, it will reduce information asymmetry to reduce conflict between agents and principal (agency conflict) so that it has a positive impact on external information that will give a good image and increase the stock market in the community

In developed countries, governance has been carried out evenly because there are clear rules and norms, this is the impact of the needs of the economic system that has been financial Crises (Aldamen \& Duncan, 2016). The success of governance in a country is determined by the first few parties the government as the regulator that regulates how the implementation of GCG must be applied and legal sanctions if not implemented, the business world as market players where GCG is the basic guideline for business implementation and finally the community as users resulting from a business entity is the affected party from the company can carry out social control in an objective and responsible manner. From the various results of studies conducted by various national and international independent research institutions, it shows the low understanding of the important and strategic meaning of the application of GCG principles by business people in Indonesia. In addition, organizational culture also influences the implementation of GCG in Indonesia(Thomas S. Kaihatsu, 2006).

In addition to good governance in an entity, there are things that are not less important in the continuity of business entities, namely the form of social responsibility towards the community or often known as CSR. and CSR is a form of concern for entities that must be based on triple bottom lines or three basic principles, namely Profit, People and Planet(Elkington, 2001) Profit means that the firm should try to improve the economy to make the firm continue to advantage. People mean that the firm must have a concern for human prosperity and finally the Planet means that the firm must have concern for the environment and the sustainability of biodiversity

CSR implementation in Indonesia is still philanthropic in accordance with the core business of the company. In fact, there are still many CSR activities that are not yet targeted, such as the case of PT Antam (Persero) Tbk 
in the provincial or district government where CSR activities for airport development, for sub-district office operations and other activities whose essence is not right on target there is even a political content that makes the company a dairy cow, so in the implementation of CSR a control system is needed from all parties involved both internally and externally.

In the Enron Case, Ethics has been the fundamental cause of the collapse of big companies, ethic is an analysis of the application of concepts such as right, wrong, bad and responsibility. Ethics is a value or quality which becomes a study of standard and moral assessment, so that ethical application is needed entity in supporting the company's goals(Appelbaum, Vigneault, Walker, \& Shapiro, 2009) (Clark Williams \& Seguí-Mas, 2010).

The code of ethics in a company illustrates how business ethics applied in the company that regulates employees, leaders and all layers in the company to run the company in accordance with the code of conduct, the violation of these regulations is a violation of law. Dam, a company implementing good corporate governance, is only a shell if it is not supported by ethics by leaders and employees, as well as the implementation of CSR without ethics, it will become a waste or meaningless activity. If ethics has been implemented and has become an obligation, it will be attached to all activities carried out by the company including the implementation of GCG, and CSR will be right in target if it is based on ethic in implementation or its implementation so that the writer uses ethics as a variable moderation that can strengthen the implementation of governance and implementation of CSR carried out by the company, (Tuan, 2014) explains that ethics fosters the implementation of CSR that is ethical and will have an impact on corporate governance.

The application of ethics and measurement of ethics with content analysis into the variables of GCG and CSR has become a novelty in this research so as to strengthen the realization of GCG and CSR in the company. The implementation of GCG and CSR in companies support the company's goal is profit oriented, in maintaining business continuity and public trust business credibility can be seen from stock returns and that is not less important in GCG implementation and CSR is business ethics, from the description above the writer are fascinated in doing research on " The Implementation of GCG, CSR toward stock return and ethics as moderating variables"

\section{Literature review and Development}

(Solomon, 2008) Corporate Governance also organize the connection and responsibility or accountability of the company to the members of non-shareholder stakeholders. Corporate Governance as the principle that directs and controls the company (all company activities) whose purpose is to achieve balance and power and then the company's authority in providing accountability to the shareholders particularly and stakeholders generally(Achmad;mas Daniri, 2005).

The variable Good Corporate Government the author takes 5 five aspects namely, Ownership of Institutional, Ownership of management, the Size of the board of commissioners, the proportion of the Board of Commissioners, number of the Audit committee into one hypothesis. The purpose of GCG (Good Corporate Governance) Cultivating obedience in implementing governance to become a real culture (Conformed GCG $=$ Culture), increasing the value of shares in the long run but look at the various interest of the stakeholders. Being able to create a highly competitive company, for sustainable business development and finally is to ensure the achievement of sustainable growth and profit. The issue of corporate governance arises because of the separation between control of the firm and the ownership. The presence of good governance such as monitoring by increasing the company's share ownership by management and the role of monitoring by an independent board of commissioners is expected to improve company performance

(Gemegah, 2015) the results of his research prove that the Board Size has significant positive relation with stock return synchronicity. This positive relationship shows that a larger Board size is related with a higher level of synchronicity. It is not proven that the audit quality used by companies will get a significant relationship with the stock return, the board composition is positively related to company transparency. Institutional Owners are institutional ownership of companies owned by institutions or institutions such as insurance companies, banks, investment companies and ownership of other institutions (Tarjo, 2008). With the ownership of shares by nonpersonal institutions provides a level of supervision of the company's management performance can be controlled so that it is expected to minimize information asymmetry. Where companies are given strong control to perform performance and disclosure to the maximum and will have an impact on company profits that are significant, and are expected to be a positive signal to move land prices towards higher (rising) so that returns in each period are created according to the research of Cyert et al. , (1998); Holderness and Sheehan (1988) Barclay and Holderness (1990), Pound (1998).

\section{H1: Good corporate governance has positive influence on stock return}

(Suharto, 2006) explains, CSR is the operation of a business which committed not only for increasing company profits financially but also for the social development regional economy in a holistic, institutionalized and sustainable manner. William LaGore, Lois Mahoney and Linda Throne (2016) in the research title variables 
use the term Standalone $\times$ CSR performance for every three steps from CSR to test whether there are differences between companies that publish independent CSR reports and the research result shows There is no effect between any form of CSR score and Cumulative stock return. Fiori et al (2007), the yield of the study mention that CSR parameters (Environment, Employment, and Community) have no significant effect on stock prices, while Titisari et al. (2010) study results Environment and community variables are positively correlated with CAR, while employment parameters are negatively correlated with CAR. So the hypothesis taken by researchers related to CSR

\section{H2: CSR Influential Positive to Stock return}

(Spillane, 1976) about the notion of ethics, namely considering or paying attention to human behavior in taking decisions related to morals. Ethics leads more to the use of human reason with objectivity to determine right or wrong and one's behavior to others.(Rossouw, 2010) (McNutt \& Batho, 2005): work ethics is a reference used by an individual person or company as a guideline in carrying out work activities of his business, so that the activities they do do not harm other individuals or institutions. Ethics are beliefs about right and wrong actions, or good and bad actions, which influence other values (Ebert, 2010)

The company's code of ethics aims to collect key values from a company and be expected to describe these values. One important but the less attention-grabbing function of the code of ethic includes the fact that by making company values increasingly explicit, an effective code will provide ethical justification to each member of the company where effective code can be used to solve individual dilemmas and organization. The application of company ethics becomes important in the creation of all aspects in each activity and the application of all systems implemented by the company.

Disclosure of ethics in the company will give a positive impression and the impact of market and investor trust in the company. Boatright, 2000; Coughlan, (2005: 45) explains that if a decision maker will consider this ethical justification along with economic and legal justification before making a choice. Cummings (2000) explained that ethical selection is not harmful but also does not help the profitability of companies in America. Finally, in this study the authors place ethics as a moderating variable which assumes that ethics can strengthen the implementation of GCG and the implementation of CSR that has been implemented by the company and outlines the hypothesis:

\section{H3: ethics as a moderating variable strengthens the effect of institutional ownership on stock return}

Corporate Social Responsibility (CSR) is a program undertaken by companies and some companies are required in accordance with Article 74 of the Limited Liability Company Law (UUPT) and some are still voluntary and are considered as corporate ethics (Jones et al., 2014) mentioning CSR as having responsibility moral responsibility by having morals and ethics to provide benefits to society, corporate CSR can be philanthropic, but sometimes CSR is only a corporate image and obeying government regulations, so that ethical factors being a principle that can strengthen the implementation of CSR and will strengthen its influence on the economy, including in the stock return, Dentchev (2004) in his article on corporate social responsibility as a business strategy shows that ethics have varying results, thus increasing stakeholder relations. holder on the positive side, while the negative side effects company relationships

\section{H4: Ethics As a moderating variable strengthens the influence of CSR on Stock Return}

\section{Research Methods}

This research is quantitative research, which is analyzing the data in the form of numerical (numbers) managed by statistical methods,(Arikunto, 2013) by using the Verification Method, which is a method of testing predetermined goals whether it is appropriate or not with existing theories to make new theories and creating new knowledge. The research hypothesis including the Associative hypothesis is the presumption of the relationship between two or more variables, with cross section data consisting of 69 manufacturing companies in the chemical industry, in 2017 with annual report data and sustainability reports from the Indonesian stock exchange (www.idx.co.id)

\section{Good Corporate Governance}

The author's GCG measurements add up from the 5 aspects below 
Table 3.1 Measurment GCG

\begin{tabular}{|l|l|}
\hline \multicolumn{1}{|c|}{ Indicators } & \multicolumn{1}{|c|}{ Measurements } \\
\hline 1. Institutional Ownership & $\begin{array}{l}\text { Variable Institutional Ownership is an external governance mechanism variable. In } \\
\text { this study, institutional ownership variables were obtained from the total } \\
\text { percentage of shares held by institutional } \\
\text { Zimmermann, 2004) }\end{array}$ \\
\hline 2. Managerial Ownership & $\begin{array}{l}\text { ownership managerial is the number of shares of all of the capital who use and } \\
\text { measured by the percentage of stock that is owned by the board of commissioner } \\
\text { divided the number of stock }\end{array}$ \\
\hline $\begin{array}{l}\text { 3. Size of the Board of } \\
\text { Commissioners }\end{array}$ & $\begin{array}{l}\text { The board of commissioners is measured based on how the percentage of the } \\
\text { number of independent board members on the total number of commissioners in } \\
\text { the board of commissioners composition of the firm }\end{array}$ \\
\hline $\begin{array}{l}\text { 4. Independent Board of } \\
\text { Commissioners Proportion }\end{array}$ & $\begin{array}{l}\text { Independent commissioners proportion is measured by the total of the sum } \\
\text { independent divided by the total amount of board commissioners }\end{array}$ \\
\hline $\begin{array}{l}\text { 5. The Committee of } \\
\text { Audit }\end{array}$ & $\begin{array}{l}\text { he committee of the audit is counted with the total of audit committee members } \\
\text { from each firm used as the sample in this research }\end{array}$ \\
\hline
\end{tabular}

Corporate Social Responsibility (CSR)

The CSR measurement in this papers the author uses the CSR disclosure index, the number of provisions revealed by the standard GRI provisions in 2018 totaling 77 items so that the formula uses:

CSRDi $=$ nij / xij

$\mathrm{CSR}=$ Environmental Accounting Disclosure Index

$\mathrm{nij}=$ the number of disclosure items by the Company reveals, each item revealed is given a score of 1 and if not 0

$\mathrm{xij}=$ number of GRI provisions (77 items)

\section{Stock Return}

Stock return measurement using formula $\mathrm{P}=\frac{\mathrm{Pt}-\mathrm{P} t=1}{\mathrm{Pt}-1}$

Information ; $\mathrm{R}=$ stock return in period $\mathrm{t}, \mathrm{P}_{\mathrm{t}}=$ stock price for the year of observation,

$\mathrm{P}_{\mathrm{t}-1}=$ stock price before observation

\section{Ethics}

Measurement of Ethical variables with code of conduct, namely guidelines for corporate behavior, using analysis content with a score of 0 - 4

$0=$ If the company does not disclose the code of conduct in the Annual report

$1=$ Has a code of conduct but is not explained

$2=$ Having a Code of conduct by mentioning points in the code of conduct

$2=$ If each paragraph is explained

$3=$ If revealed in 1 special capter and contains in detail both the point of code of conduct is accompanied by an explanatory paragraph

\section{Results and Analysis of Research}

Descriptive statistics

Table 4.2 Descriptive Statistics

\begin{tabular}{|l|r|r|r|r|r|r|}
\hline \multicolumn{1}{|c|}{ N } & \multicolumn{1}{c|}{ Min } & \multicolumn{1}{c|}{ Max } & \multicolumn{1}{c|}{ Sum } & \multicolumn{1}{c|}{ Mean } & \multicolumn{1}{c|}{ standard deviation } \\
\hline GCG & 57 & 2.67 & 4.04 & 186.95 & 3.2798 & .36109 \\
GCG_ETIK & 57 & 7.21 & 49.73 & 975.32 & 17.1109 & 9.36069 \\
CSR_ETIK & 57 & .05 & .34 & 9.38 & .1646 & .05819 \\
Lnsize & 57 & 3.56 & 34.50 & 582.83 & 10.2251 & 4.37954 \\
ROE & 57 & .16 & 96.43 & 577.92 & 10.1389 & 16.48732 \\
ETIK & 57 & .33 & 1.00 & 33.55 & .5886 & .14547 \\
Valid N (listwise) & 57 & & & & & \\
\hline
\end{tabular}

Source: data processed 2018 (SPSS V20)

From the table above, it can be seen that some of the results of processing consist of

- $\quad \mathrm{N}$ is the amount of data showing 57 companies

- Minimum could be said as the lowest value of each variable in the study variable which has the lowest CSR_ETIKA value of 0.05

- score maximum in this research is the highest score of each variable the largest score in the ROE 
variable reaches 96.43

- Sum is the sum of all data in the variable and the largest number is in the GCG_ETIKA variable reaching 17,1109

- Mean shows the average of each, each variable can be seen the mean GCG * Ethics has the biggest mean value in GCG Etika

- Standard Deviation is the average disperse of each sample and research variables, variables that have the highest standard deviation in the variable ROE

\subsection{Data quality testing, Analysis of Research Results and Discussion}

In this study data quality testing used the classical assumption test with the purpose of the data being analyzed to assess whether in a linear Ordinary Least Square (OLS) regression model there are classical assumption problems. The result all data were normally distributed with asymp values, sig 0.44, all data did not have multicollinitas and heterokedacity problems did not occur in the research regression model.

The results of hypothesis testing in this study using multiple regression analysis, and rank spearment correlation, the test results describe for the four hypotheses can be seen in table 4.3 .1 as follows

Tabel 4.2.1Regresi

\begin{tabular}{|l|r|r|r|r|r|}
\hline & \multicolumn{2}{|c|}{ Unstandardized Coefficients } & Standardized Coefficients & \multirow{2}{*}{ S } & \\
\cline { 2 - 5 } & \multicolumn{1}{|c|}{$\mathrm{B}$} & Std. Error & Beta & \\
\hline (Constant) & -3.324 & 1.159 & 2.869 & .006 \\
GCG & .082 & .038 & .786 & 2.147 & .037 \\
CSR & 4.144 & 2.392 & .373 & 1.733 & .089 \\
GCG_ETIK & -.120 & .057 & -.965 & 2.114 & .040 \\
CSR_ETIK & 6.718 & 3.305 & .335 & 2.033 & .047 \\
Lnsize & -.057 & .035 & -.212 & 1.635 & .108 \\
ROE & -.005 & .009 & -.066 & -.494 & .624 \\
\hline
\end{tabular}

a. Dependent Variable: RS

From table 4.6 the multiple regression equation is obtained so that it can be described by the equation $\mathrm{SR}=-3.324+0.082 \mathrm{GCG}+4.144 \mathrm{CSR}-0,120 \mathrm{GCG} *$ Ethic $+6.718 \mathrm{CSR} *$ Ethic -0.057 LNSIZE-0.05 ROE

From the above equation can explain the influence between variables or can explain about

$\alpha=$ constant value of $-3,324$ means that if it is not good governance and not implemented CSR and there is no ethical application, the return stock value will decrease by 3,324 or $3.3 \%$

$\beta 1=$ Niai coefficient 0.08 of GCG or the value of the effect of GCG on Stock return means that implementing GCG will increase return stock by $8 \%$

$\beta 2=$ Niai coefficient 4.144 from CSR or the value of CSR on Stock return means that implementing CSR will increase the return stock by 4.144

$\beta 3$ = The coefficient value of -0.12 from ETHICS which cannot strengthen the implementation of GCG and cannot affect the stock return,

$\beta 4=$ The coefficient value of -0.057 from SIZE has a negative effect toward stock return

$\beta 5=$ Niai coefficient -0.057 of ROE has a negative effect toward stock return

The results of the study seen from the above analysis can be explained in table 4.3.2

Table 4.3.2Results

\begin{tabular}{|l|l|l|l|l|}
\hline Variabel & Koefisien & Sign & $\begin{array}{l}\text { Correlation to } \\
\text { Stock Return }\end{array}$ & Result \\
\hline $\begin{array}{l}\text { Good Corporate } \\
\text { Governance (GCG) }\end{array}$ & 0.082 & 0,015 & 0,265 & $\begin{array}{l}\text { Correlation is very weak, and have } \\
\text { effected a positive significant }\end{array}$ \\
\hline CSR & 4.144 & 0,04 & 0,09 & $\begin{array}{l}\text { Correlation is very weak, has a positive } \\
\text { and significant effect }\end{array}$ \\
\hline Ethic*GCG & $-0,120$ & 0,02 & 0,168 & $\begin{array}{l}\text { Correlation is very weak, negative and } \\
\text { significant effect }\end{array}$ \\
\hline EThic*CSR & 6,718 & 0,04 & 0,317 & $\begin{array}{l}\text { Correlation is sufficient, has a positive } \\
\text { and significant effect }\end{array}$ \\
\hline SIZE & $-0,057$ & 0,05 & $-0,261$ & $\begin{array}{l}\text { Sufficient negative correlation, negative } \\
\text { and not significant effect }\end{array}$ \\
\hline ROE & $-0,005$ & 0,31 & 0,062 & $\begin{array}{l}\text { Correlation is very weak, negative and } \\
\text { not significant }\end{array}$ \\
\hline R square & .177 & & & \\
\hline
\end{tabular}




\section{Discussion}

- Hypothesis 1 is a positive influence of Good corporate governance on the stock return is accepted means that the implementation of Good Corporate Governance with disclose annual reports and Sustainability reporting can have an effect on prospective investors in deciding to invest, according to (Awan Werdhy Ajiwanto, 2016) that GCG has a significant effect toward stock returns even though partially has no effect significant, according to (Mitton, 2002);(Suriyan Somphong, Supitr Samahito, 2015)(Wahyudin \& Solikhah, 2017), corporate governance has a positive effect on firm performance. This illustrates that the implementation of GCG in a company is an interconnected whole, investors do not see separately in disclosure reports or indicators but look at various aspects and in whole mutually supportive, investors believe that every report on disclosure of corporate governance contains information about developing and increasing company value, managing resources and risks more effectively and efficiently. enhancing discipline and responsibility of company organs to preseve the interests of stockholder and stakeholders of the company, increasing the contribution of the company (especially government companies) to the national economy, increasing national investment; and the success of privatization programs of government companies

- Hypothesis 2 is a positive effect of CSR on the stock return is accepted, it means that the realization and disclosure of CSR in the report can affect stock returns in the company. This is in line with (Mingming Feng, Xiaodan "Abby" Wang, 2017);(Arendt \& Brettel, 2010); (Vurro \& Perrini, 2011) that implementing CSR simultaneously proves CSR simultaneously, showing that environmental, social and economic CSR variables have a positive effect on as well as stock returns. Likewise with (Awuy, Sayekti, \& Purnamawati, 2016), mentioning CSR has an effect on Cumulative Abnormal return. Both studies provide evidence that CSR disclosure measured by three aspects, is economic aspects, environmental aspect and social aspects partially does not have a significant effect but if together it will provide complete information on how to manage and assume corporate social responsibility and how CSR activities provide an image positive for company performance so that investors and the public trust the stock price of the company will continue to be progressive and investors will gain capital, this results in indirectly stock returns will have a positive effect. In line with melle theory of instrumental theory where instrumental theory, explains corporations seen only as instruments for wealth properties, and its social activities are only a tool to achieve economic results; return stock is an economic achievement of the company.

- Hypothesis 3 is the ethics of moderating the effect of GCG on stock returns rejected, meaning that the ethics applied by the company cannot strengthen the implementation of GCG on stock returns, this is due to the possibility that the company's GCG has been implemented so well that it will automatically create an ethical and ethical work culture already has no role in the work environment. paths with management theory where describing the situation of managers is not motivated by individual goals but rather aimed at their main targets for the benefit of the organization. So that the application of ethics cannot strengthen the implementation of corporate governance to make company value higher, not in accordance with (Ariesti, Yolanda, \& Hia, 2014) (Prieto, Mathur-Helm, \& Dawson, 2018) which explains that ethical business has a relationship that significant and positive with the implementation of GCG.

- Hypothesis 4 is the ethics of moderating the influence of CSR on return stock is accepted, means that the Ethics applied in the implementation of CSR can strengthen the effect of CSR on the returnstock. CSR aktivities in firm clearly describing ethics is one of the company's responsibility carry out company activities. (Garriga \& Melé, 2004) mention ethical theory, based on the company's ethical responsibility to society. The implementation of CSR to the public both directly and indirectly can provide information to the market and can invite market reactions as an impact of the good image, the company value will be lifted, including not closing the possibility of increasing stock market prices, according to Fauzan 2011. Companies that implement their CSR are not based on certain tendencies, they only act for their obligations(Tuan, 2014);(Choi, 2014)

\subsection{Conclusions, Limitations of Research, Implications Conclusion}

The outcome of this research Good Corporate Governance has a positive effect toward stock return and execution of good governance, it creates public trust, investor confidence and markets so that the value of the company increases. CSR has a positive effect toward return stock. CSR activities and CSR reporting provide a positive image for the company and generate trust from all circles and shareholders, especially the implementation of CSR can't be separated from the value of marketing or marketing in increasing the value of the company. Ethic can't strengthen the effect of Good Corporate Governance on Stock returns, this is contrary with Agency theory because with good governance applied good business ethics should be able to increase market confidence, but conversely if ethics in the company is only limited to slogans and companies can't make the market believe the existence of ethics that become a culture in the company can't foster public trust. Ethics 
can strengthen the effect of Corporate Social Responsibility on Stock return. Implementation of ethics in corporate CSR activities will make the CSR program more effective rather than just fulfilling obligations but implementing CSR programs in accordance with business core, not just philatropic but in accordance with the business lines carried out by each company will make the community benefit from CSR programs, besides The CSR program will look real, not only report it, the impact on economic improvement will be obtained

\section{Research Limitations}

This study has limitations that require improvement and development in future studies. The limitation in this study is that the focus on manufacturing companies is not all sectors so that conclusions cannot apply to all types of companies. Only domestic companies that implement CSR are still Voluntary in nature, most likely not applicable to countries that are already mandatory.

\section{Implications}

The finding of this research state that the implementation of GCG and CSR will be economically profitable or influence the stock return and will raise the value of the company so that the application of GCG and CSR is a matter of concern for the market, for investors and encourage companies to implement business ethics in implementation. So that encouraging policy makers in the company will apply more maximally both business ethics in GCG and Business ethics in CSR.

\section{References}

Achmad;mas Daniri. (2005). Good Corporate governance: Konsep Dan penerapan Dalam Konteks Indonesia. jakarta: Ray Indonesia.

Aldamen, H., \& Duncan, K. (2016). Does good corporate governance enhance accruals quality during financial crises? Managerial Auditing Journal, 31(4-5), 434-457. https://doi.org/10.1108/MAJ-06-2015-1206

Appelbaum, S. H., Vigneault, L., Walker, E., \& Shapiro, B. T. (2009). (Good) corporate governance and the strategic integration of meso ethics. Social Responsibility Journal, 5(4), 525-539. https://doi.org/10.1108/17471110910995366

Arendt, S., \& Brettel, M. (2010). Understanding the influence of corporate social responsibility on corporate identity, image, and firm performance. Management Decision, 48(10), 1469-1492. https://doi.org/10.1108/00251741011090289

Arikunto, S. (2013). Prosedur Penelitian: suatu pendekatan praktek. (Rineka Cipta, Ed.). Jakarta.

Awan Werdhy Ajiwanto, J. H. (2016). Pengaruh Good Corporate Governance Terhadap Return Saham Perusahaan Yang terdaftar di CGPI dan Bursa Efek Indonesia. Jurnal Ilmiah Mahasiswa FEB Univesritas Brawijaya, 2(2).

Awuy, V. P., Sayekti, Y., \& Purnamawati, I. (2016). Pengaruh Pengungkapan Corporate Social Responsibility ( CSR ) Terhadap Earnings Response Coefficient ( ERC ). Jurnal Akuntansi Dan Keuangan, 18(1), 15-26. https://doi.org/10.9744/jak.18.1.15-26

Beiner, S., Drobetz, D. W., Schmid, F., \& Zimmermann, H. (2004). Is board size an independent corporate governance mechanism? Kyklos, 57(3), 327-356. https://doi.org/10.1111/j.0023-5962.2004.00257.x

Choi, H. K. M. B. K. (2014). How an organization's ethical climate contributes to customer satisfaction and financial performance ",. European Journal of Innovation Management, 17(1), 85-106.

Clark Williams, C., \& Seguí-Mas, E. (2010). Corporate governance and business ethics in the European Union: a cluster analysis. Journal of Global Responsibility, 1(1), 98-126. https://doi.org/10.1108/20412561011039735

Ebert, R. W. G. J. (2010). Bisnis (8th ed.). jakarta: Erlangga.

Elkington, J. (2001). Enter the Triple Bottom Line, 1(1986), 1-16.

Garriga, doctoral E., \& Melé, D. (2004). "Corporate Social Responsibility Theories: Mapping the Territory" ("Responsabilidad social corporativa: un mapa del territorio"). Journal of Business Ethics 53, 51-71.

Gemegah, M. N.-G. G. A. B. A. (2015). Corporate governance and transparency: evidence from stock return synchronicity, 7(2), 157-179.

Jones, P., Hillier, D., Comfort, D., Jones, P., Hillier, D., \& Comfort, D. (2014). Assurance of the leading UK food retailers' corporate social responsibility / sustainability reports. https://doi.org/10.1108/CG-03-20110027

McNutt, P. A., \& Batho, C. A. (2005). Code of ethics and employee governance. International Journal of Social Economics, 32(8), 656-666. https://doi.org/10.1108/03068290510608183

Mingming Feng, Xiaodan “Abby" Wang, J. G. K. (2017). "Corporate Social Responsibility and Firm Financial Performance: Comparison Analyses across Industries and CSR Categories. American Journal of Business, 4(1). https://doi.org//doi.org/10.1108/AJB-05-2016-0015

Mitton, T. (2002). A Cross-Firm Analysis of the Impact of Corporate Governance on the East Asian Financial Crisis. Journal of Financial Economics, 64, 215-241.

Rossouw, G. J. (2010). The ethics of corporate governance. International Journal of Law and Management, 
51(1), 5-9. https://doi.org/10.1108/17542430910936628

Solomon, N. M. B. \& J. (2008). Corporate governance, Accountability And Mekanisms of Accountability:on Overview. Accounting,Auditing And Accountability journal.

Spillane, J. J. (1976). Corporate Social Responsibility in the Southeast Asian Context.

Suharto, E. (2006). pekerja Sosial Industri,CSR dan COmDev, workshop tentang Corporate Social Responsibility (CSR). Bandung: Lembaga Studi Pembangunan(LSP)-STKS.

Suriyan Somphong, Supitr Samahito, I. K. (2015). Corporate Governance on the National Olympic Committee of Thailand. Open Journal Of Social Sciences, 3(12).

Thomas S. Kaihatsu. (2006). Good Corporate Governance Dan penerapannya Diindonesia. Jurnal Manajemen Dan Kewirausahaan, Vol 8(N0 1), 1-9. https://doi.org/10.1021/bk-1991-0462.ch006

Tuan, L. T. (2014). Clinical governance, corporate social responsibility, health service quality, and brand equity. Clinical Governance, 19(3), 215-234. https://doi.org/10.1108/CGIJ-02-2014-0007

Vurro, C., \& Perrini, F. (2011). Making the most of corporate social responsibility reporting: Disclosure structure and its impact on performance. Corporate Governance, 11(4), 459-474. https://doi.org/10.1108/14720701111159280

Wahyudin, A., \& Solikhah, B. (2017). Corporate governance implementation rating in Indonesia and its effects on financial performance. Corporate Governance (Bingley), 17(2), 250-265. https://doi.org/10.1108/CG02-2016-0034 